\title{
Zootechnical and economic performance indexes of dairy herds with different production scales
}

\section{Índices de desempenho zootécnico e econômico de rebanhos leiteiros com diferentes escalas de produção}

\author{
Rodrigo de Andrade Ferrazza ${ }^{1}$; Marcos Aurélio Lopes ${ }^{2 *}$; \\ Fabio Raphael Pascoti Bruhn ${ }^{3}$; Flavio de Moraes ${ }^{4}$
}

\begin{abstract}
This study aims to estimate the zootechnical and economic benchmarks of milk production systems, analyze production scale effects on dairy farming returns, and identify the system components that best represent the total and effective operational costs. We analyzed 22 size, zootechnical and economic performance indexes from 61 dairy farms located in Minas Gerais state, Brazil. The sample of herds were clustered according to three production strata. The results were compared using analysis of variance (normal distribution) and Kruskal-Wallis (non-normal distribution) tests, and post-hoc comparisons were undertaken with Fisher's least significant difference test. The relationship between some variables was tested using the Pearson correlation test. The production scale was best defined by the number of lactating cows $(\mathrm{r}=0.96)$ in comparison to the area $(\mathrm{r}=0.83)$. The production scale proved to be a suitable criterion for the analyses between different groups of producers, and it is more easily obtained and probably provides more accurate results. The milk production systems studied presented higher zootechnical indexes than those found in average of Brazilian farms, but lower than international indices or technologically advanced farms from other Brazilian regions. A greater production scale is a desirable condition, although it failed to ensure the economic efficiency of the herds studied. The components of total and effective operating costs that had the greatest representativeness were, in descending order, food and labor.
\end{abstract}

Keywords: Benchmark. Dairy cattle. Production cost. Profitability. Stratification criterion.

\section{Resumo}

Objetivou-se com este estudo estimar índices de desempenho zootécnico e econômico de referência, analisar a influência da escala de produção sobre a rentabilidade da atividade leiteira e identificar os componentes que exerceram maiores representatividades sobre o custo total e operacional efetivo. Foram analisados 22 índices de tamanho, zootécnico e econômico de 61 sistemas de produção de leite, localizados no estado de Minas Gerais, Brasil. Os rebanhos foram agrupados em função de três estratos de produção. Os resultados foram comparados pelos testes de ANOVA (distribuição normal) e KruskalWallis (distribuição não normal), complementados pelo teste de comparação de médias (Fisher's least significant difference). O relacionamento entre algumas variáveis foi testado usando o teste de correlação de Pearson. A quantidade de vacas em lactação $(r=0,96)$ definiu melhor a escala de produção

\footnotetext{
${ }^{1}$ Dr. em Biotecnologia Animal, Universidade Estadual Paulista, UNESP, Botucatu, SP, Brasil. E-mail: rodrigoferrazza@yahoo. com.br

${ }^{2}$ Prof. Titular do Departamento de Medicina Veterinária, Universidade Federal de Lavras, UFLA, Lavras, MG, Brasil. E-mail: malopes@dmv.ufla.br

${ }^{3}$ Dr. em Medicina Veterinária, Universidade Federal de Lavras, UFLA, Lavras, MG, Brasil. E-mail: fabio_rpb@yahoo.com.br

${ }^{4}$ M.e em Medicina Veterinária, Universidade Federal de Lavras, UFLA, Lavras, MG, Brasil. E-mail: f.demoraes2009@gmail.com

* Author for correspondence
} 
em comparação à área $(\mathrm{r}=0,83)$. A escala de produção mostrou-se um critério adequado para análise entre grupos distintos de produtores, além de obtenção mais simples e, provavelmente, de maior acurácia. Os sistemas de produção de leite estudados apresentaram índices zootécnicos superiores à média de fazendas brasileiras, porém inferiores aos índices internacionais ou de fazendas tecnificadas de outras regiões brasileiras. Maior escala de produção é uma condição desejada, mas não garantiu a eficiência econômica dos rebanhos estudados. Os itens componentes do custo total e do custo operacional efetivo que exerceram maiores representatividades foram, em ordem decrescente, alimentação e mão de obra. Palavras-chave: Critério de estratificação. Custo de produção. Índice de referência. Lucratividade. Pecuária de leite.

\section{Introduction}

In recent decades, the dairy industry has been facing tremendous challenges, such as the globalization of the economy, the liberalization of agricultural trade policy, and the structural changes toward intensification of dairy farming systems, in order to remain in business (HEMME et al., 2014). Based on this background, farmers are required to manage their enterprises with the efficiency and agility that is required to maintain market competitiveness. Zootechnical and economic performance indexes provide information to manage dairy farming in a highly competitive and uncertain environment with reduced profit margins and could be useful to set new targets.

The Brazilian milk production chain is dynamic and heterogeneous. Various classification criteria of milk production systems have been adopted and their selection varies according to the objectives. Production scale is a key factor in producing attractive economic indexes (OLIVEIRA et al., 2001). Farms with larger production volumes had smaller mean costs and were more profitable previously (ARÊDES et al., 2006; GONÇALVES et al., 2008). However, none of those studies employed a statistical method in which the adopted stratification criterion could be analyzed.

Furthermore, identification, quantification, and establishment of technical, managerial, and economic benchmarks are of practical interest of technicians and ranchers on dairy farms. The use of benchmarks based on common factors among systems, such as the production scale, may provide a basis to design plans, set goals, monitor results, and make strategic decisions. On the other hand, policymakers could use this knowledge to identify and target public interventions to improve farm productivity and economic efficiency of the activity.

In this paper, the factor production scale was tested to compare zootechnical and economic performance indexes of typical Brazilian dairy herds. The most significant components of the total operational costs and effective operational costs were also identified.

\section{Materials and Methods}

The data used in this study were from 61 dairy farms located in Minas Gerais (MG) state, Brazil, between January 2002 and December 2011. The size, technological, and economic performance indexes used are described in Table 1. These indexes were selected considering data availability and relevance.

The production systems were allocated to one of the three production strata (small, medium, and large) to meet the research goals of this study and to achieve a better interpretation of results. Producers whose daily milk production values were lower than $200 \mathrm{~L}$, from 201 to $1,000 \mathrm{~L}$, and higher than 1,001 L were considered small, medium, and large producers, respectively.

Costs were estimated in accordance with the method of operational (MATSUNAGA et al., 1976) and total (LOPES et al., 2007) costs. The following criteria were considered in the calculation of production cost: $6 \%$ return on capital per year, which approximately corresponds to the rate of savings; linear depreciation method to represent 
the cost of substituting the goods due to physical or economic wear: $\mathrm{D}=\frac{\mathrm{P}_{\mathrm{c}-} \mathrm{S}_{\mathrm{v}}}{\mathrm{U}_{\mathrm{l}}}$, where $\mathrm{D}=$ Annual depreciation value, $\mathrm{P}_{\mathrm{c}}=$ Purchase cost (new asset), $\mathrm{S}_{\mathrm{v}}=$ Salvage value, and $\mathrm{U}_{1}=$ Useful life (HOFFMANN, 1987); and the grouping of items that contribute to the operational costs of milk, such as feeding, labor, health, breeding, milking, fixed taxes, electric power, and miscellaneous expenses. Expenses related to the use of recombinant bovine somatotropin were allocated to health, whereas machinery rental was allocated to other expenses. The representation of these items in relation to total operational costs (TOC) and effective operational costs (EOC), expressed as percentages, was also calculated. The method proposed by Lopes et al. (2011) was used to calculate profitability and return on capital. All calculations were performed using MS Excel ${ }^{\circledR}$ electronic sheets (Microsoft Corp., Redmond, WA, USA).

Table 1. Index descriptions, abbreviations, equations, and units.

\begin{tabular}{|c|c|c|c|}
\hline Index & Abbreviations & Equation & Unit \\
\hline \multicolumn{4}{|c|}{ Size indexes } \\
\hline Daily milk production & DMP & --- & $\mathrm{L}_{\text {day }}{ }^{-1}$ \\
\hline Area stocked with dairy cows & $\mathrm{Ar}$ & --- & ha \\
\hline Contractor labor & $\mathrm{CL}$ & --- & wd \\
\hline Hired labor & HL & --- & wd \\
\hline Dairy cow number & $\mathrm{DCN}$ & --- & head \\
\hline \multicolumn{4}{|l|}{ Technical indexes } \\
\hline Dairy cow stocking rate & DCSR & Number of dairy cows/Area & head ha-1 \\
\hline Milk production per dairy cow & $\mathrm{DMP} / \mathrm{DCN}$ & Daily milk production/Dairy cow number & $\mathrm{L}_{\mathrm{e}} \mathrm{r}^{-1}$ \\
\hline Dairy cows per worker day & $\mathrm{DCN} / \mathrm{L}$ & Dairy cow number/Total annual labor & head $w^{-1}$ \\
\hline Annual milk production by labor & $\mathrm{AMP} / \mathrm{L}$ & Annual milk production/Total annual labor & $\mathrm{L} w d^{-1}$ \\
\hline Annual milk production by area & $\mathrm{AMP} / \mathrm{A}$ & Annual milk production/Farm area & $\mathrm{L}_{\text {ha }}$ year ${ }^{-1}$ \\
\hline \multicolumn{4}{|c|}{ Economic indexes } \\
\hline $\begin{array}{l}\text { Milk gross profit (MGR) by total gross } \\
\text { profit (TGR) }\end{array}$ & MGR/TGR & $\mathrm{MGR} / \mathrm{TGR} \times 100$ & $\%$ \\
\hline $\begin{array}{l}\text { Operational expenses excl. depreciation } \\
\text { (EOC) by TGR }\end{array}$ & EOC/TGR & $(\mathrm{EOC} / \mathrm{TGR}) \times 100$ & $\%$ \\
\hline Operational expenses (TOC) by TGR & TOC/TGR & $(\mathrm{TOC} / \mathrm{TGR}) \times 100$ & $\%$ \\
\hline Unitary EOC by milk price (MP) & EOCun/MP & $($ EOCun/MP) $\times 100$ & $\%$ \\
\hline Unitary TOC by milk price & TOCun/MP & $($ TOCun/MP $) \times 100$ & $\%$ \\
\hline Total unitary cost by milk price & TCun/MP & $(\mathrm{TCun} / \mathrm{MP}) \times 100$ & $\%$ \\
\hline Ratio of fixed cost by total cost & $\mathrm{FC} / \mathrm{TC}$ & $(\mathrm{FC} / \mathrm{TC}) \times 100(\%)$ & $\%$ \\
\hline Depreciation by TOC & $\mathrm{D} / \mathrm{TOC}$ & $(\mathrm{D} / \mathrm{TOC}) \times 100$ & $\%$ \\
\hline Profitability 1 & P 1 & $($ Profit $/$ profit $) \times 100$ & $\%$ \\
\hline Profitability 2 & P 2 & $($ Net profit/profit $) \times 100$ & $\%$ \\
\hline Return on capital 1 & R 1 & $($ Profit $/$ invested capital $) \times 100$ & $\%$ \\
\hline Return on capital 2 & $\mathrm{R} 2$ & $($ Net profit/invested capital $) \times 100$ & $\%$ \\
\hline
\end{tabular}

A Kolmogorov-Smirnov test was performed to evaluate the distribution of continuous variables. The results were expressed as the mean \pm standard deviation for normal distributions, and median and quartile intervals for non-normal distributions (DUQUIA; BASTOS, 2006). Comparisons were performed using analysis of variance (ANOVA) complemented by a least significant difference (LSD) test for multiple comparisons when the data showed a normal distribution. The comparisons between the groups were performed with a Kruskal-Wallis test complemented by an LSD 
test for multiple comparisons between the ranked means of the variables when the data failed to show a normal distribution. The differences were considered statistically significant when $\mathrm{P}<0.05$. The relationship between certain variables was tested and all statistical analyses were performed using the software R, version 2.15.2.

\section{Results and Discussion}

The number of small-, medium-, and largescale production systems were $24(39.3 \%), 28$ (45.9\%), and 9 (14.8\%), respectively. Numerous indexes significantly differed according to the milk production strata. Therefore, the methodology used in the current study supports the comparison of performance indexes based on production scale factor, aiming to generate more robust reference data. In addition, production scale has an advantage as it is more easily obtained and probably more accurate than the type of husbandry system (FERRAZZA et al., 2017), and could be adopted for comparisons between different groups of producers.

The indexes of area size and number of lactating cows significantly differed $(\mathrm{P}<0.05)$ among the small-, medium-, and large-scale production groups (Table 2), and were positively correlated with daily milk production. However, the number of lactating cows ( $\mathrm{r}=0.96)$ better defined the production scale than the area $(r=0.83)$. It was also noted that animal productivity was not the best determinant of production volume, which had a moderate correlation of 0.46 between milk production per lactating cow and production volume. This result suggests that factors associated with animal productivity, including genetic patterns and nutritional status of the animals, could be prioritized in such herds.

The median amount of hired labor (HL) of the sample was 1.0, 2.0, and 8.0 workers and the median amount of family labor (FL) was 1.0, 0.5, and 0.0 workers for the small-, medium-, and largescale production systems, respectively. A significant difference $(\mathrm{P}<0.05)$ was observed among production scales (Table 2), and a linear, positive, and strong correlation occurred between HL and daily milk production (DMP) $(\mathrm{r}=0.88)$, suggesting that these two variables tend to increase concurrently. The predominance of $\mathrm{HL}$ was observed in all production strata. Our data showed a greater contribution of FL in the smaller production strata and greater contribution of HL in the larger production strata, which corroborates the report by the Agriculture and Livestock Federation of MG (FAEMG, 2006).

When adding family and hired labor together (total labor), the productivity patterns more clearly indicate the efficiency of this indicator. The daily milk production per total labor was 51.4, 138.2, and 476.0 liters (L) worker-day ${ }^{-1}(\mathrm{wd})$ for the small, medium, and large scales, respectively. The greater labor productivity assessed among producers with more than 1,000 L of milk day ${ }^{-1}$ may be associated with mechanical milking (FAEMG, 2006). Nascif (2008) reported a mean production of $235.2 \mathrm{~L} \mathrm{wd}^{-1}$ in MG. Increased productions of $528.5 \mathrm{~L} \mathrm{wd}^{-1}$ and $832 \mathrm{~L} \mathrm{wd}^{-1}$ were reported in benchmarking systems in the Brazilian states of Rio Grande do Sul (RS) (KRUG, 2001) and Paraná (PR) (SILVA, 2006), respectively. However, those coefficients are lower than the coefficients found in other countries, including the United States of America, where the mean production surpasses 1,605.6 $\mathrm{L} \mathrm{wd}^{-1}$ (STEPHENSON, 2000). Therefore, these results indicate low labor efficiency with non-negligible effects on production costs. Managers should evaluate labor efficiency and study the economic viability of replacing labor by labor-saving capital, including mechanical milking. Specific trainings could be also necessary to achieve better and greater labor efficiency.

No significant difference $(\mathrm{P}>0.05)$ was observed among the groups in relation to the dairy cow stocking rate (DCSR) index, although this result was expected as the large-scale production systems had more lactating cows but also a greater area. The median DCSR ranged from 0.6 to 1.4 lactating cows per hectare (Table 2) and was higher than the median 
DCSR found in MG (FAEMG, 2006) and Goiás (GO) (FAEG, 2009), which were approximately 0.4 and 0.3 , respectively. The value observed was similar to that recorded among producers of B-type milk in São Paulo (SP), which was approximately 0.4 to 1.0 (SCHIFFLER et al., 1999), although it was lower than that in the Castro region, PR, which values ranging from 1.2 to 2.1 (SILVA et al., 2006).

The values of milk production per dairy cow (DMP/DCN) recorded in this study were 3,503.0, 4,037.7, and 6,935.5 $\mathrm{L}_{\text {year }}{ }^{-1}$, whereas the values of annual milk production per area (AMP/A) were 3,875.1, 2,291.8, and 9,829.7 $\mathrm{L}_{\text {ha }}$ year $^{-1}$ for the small-, medium-, and large-scale production systems, respectively. A significant difference $(\mathrm{P}<0.05)$ occurred in the large-scale group for both indexes (Table 2), which highlights that the production factors herd and land were more intensely used by larger farms. Similarly, Fassio et al. (2006) observed that herd and land productivity increased with the production scale. The results recorded in this study in relation to DMP/DCN were similar to those reported in various studies conducted in $\mathrm{MG}$ and GO, albeit lower than those reported in the Castro region, where the DMP/DCN was $8,262 \mathrm{~L}$ in the 59 evaluated herds (SILVA et al., 2006). A number of reasons explain why production per cow is limited, including inferior genetics, low quality feeds, and diseases incidence. Land productivity is an index of the efficient use of farm forage resources and herd potential. According to FAEMG (2006), the mean milk production per area used for dairy farming was $1,188.5 \mathrm{~L}$ ha year ${ }^{-1}$. These authors reported that producers of up to $50 \mathrm{~L}^{\text {day }}{ }^{-1}$ reached the mark of $485.0 \mathrm{~L}^{2}$ a year ${ }^{-1}$, whereas those producing more than 1,000 $\mathrm{L} \mathrm{day}^{-1}$ reached 2,931.2 $\mathrm{L}$ ha year $^{-1}$ on average, corroborating that area productivity increased with the production scale of farms. However, comparison with a previous study shows the lack of intensive use of land in the herds studied as production higher than $15,000 \mathrm{~L}$ is a plausible target in Brazil (SILVA et al., 2006).
The median gross revenue derived from milk accounted for $86.0,85.4$, and $96.1 \%$ of the total gross revenue (TGR) of small-, medium-, and large-scale productions, respectively. A significant difference $(\mathrm{P}<0.05)$ occurred in the large-scale production group (Table 3 ). The gross milk revenue (GMR) accounted for 54\% of the TGR in the production systems that were least dependent on milk sales to maintain the revenue stream. A similar result was observed in other studies, where the GMR increased with the production scale. In MG, the revenue derived from milk accounted for $80.3 \%$ of the TGR on an average, reaching $84.0 \%$ in the larger production strata (FAEMG, 2006). In GO, the GMR accounted for $83.5 \%$ of the TGR, reaching $90.0 \%$ for farmers producing more than $1,000 \mathrm{~L}^{-1} \mathrm{dy}^{-1}$ (FAEG, 2009). Previous study showed that milk sales contributed to $71.9 \%$ of the gross revenue in a sample of low technology farms in $M G$, suggesting a greater contribution of animal sales in the herds with low zootechnical performance, where productivity was supposedly penalized (MARQUES et al., 2002). Other study reported that the values recorded from animal sales varied from 6.5 to $37.5 \%$ in four production systems and contributed to positive returns (LOPES et al., 2011). Similarly, Moraes et al. (2004) found that the sale of weaned calves accounted for $25 \%$ of the total revenue. Such values highlight the variation in revenue percentage composition and indicate that the amount of animal sales depends on the goals of the production system, besides requirements for increased revenue (LOPES et al., 2009) and aspects related to herd health (DEMEU et al., 2011).

The contribution of EOC to the TGR was significantly greater $(\mathrm{P}<0.05)$ in the large-scale production group. Conversely, a significant difference $(\mathrm{P}<0.05)$ only occurred between the medium and large production scales when evaluating the contribution of TOC to the TGR (Table 3 ). These results showed that the cost of milk production increases proportionally with production volume, with large producers being more efficient than the 
small and medium producers as they optimized the physical structure, as indicated by the significantly lower $(\mathrm{P}<0.05)$ index contribution of depreciation to the TOC in the large production scale.

The viability in dairy farming directly depends on production scale as such farms operate at low profit margins. The effect of economies of scale is perceived to maintain fixed costs at a constant as production increases. Therefore, a decrease in the mean unit cost per liter of milk will occur under such conditions as the "dilution" of fixed costs in a greater volume of production. This increase in the amount of milk sold may be reached by increasing the total herd size, which increases the lactating herd size, or animal productivity (LOPES et al., 2008).

The effective unit operating costs relative to the price of milk (EOCun/MP) were 67.0, 76.7, and $86.9 \%$ and the total unit operating costs relative to the price of milk (TOCun/MP) were 95.8, 89.8, and $90.5 \%$ for small-, medium-, and large-scale productions, respectively. Significant differences $(\mathrm{P}<0.05)$ were only observed between small- and large-scale productions in relation to EOCun/MP
(Table 3). Those indexes were greater than those recommended by Gomes (2000), who recorded maximum values of $65 \%$ and $75 \%$ for EOCun/ $\mathrm{MP}$ and TOCun/MP, respectively. Additionally, comparisons of the economic performance indexes between different groups of producers without considering adequate criteria, such as production scale, may be misleading and not recommended as a variation of approximately 20 and 5 percentage points was observed between the large and small scales of production in relation to the EOCun/MP and TOCun/MP indicators, respectively.

The values recorded for the fixed/total cost ratio were $33.3,30.5$, and $10.8 \%$ for small-, medium-, and large-scale productions, respectively. This ratio was only significantly different $(\mathrm{P}<0.05)$ in relation to the large-scale production (Table 3 ), which may be explained by the "dilution" of fixed costs resulting from the increased production scale. Thus, would be also expected significant differences between the small- and medium-scales, which highlights that infrastructure intended for the production of milk for medium-scale producers was not optimally employed. 


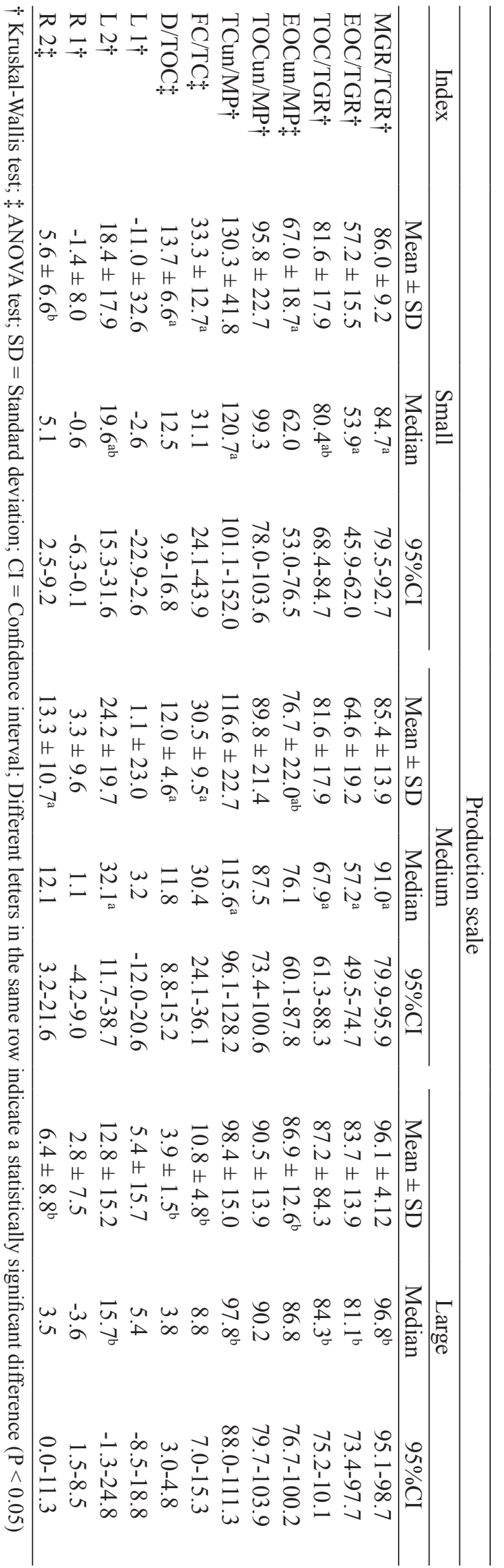

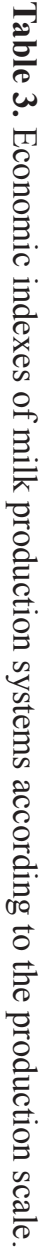

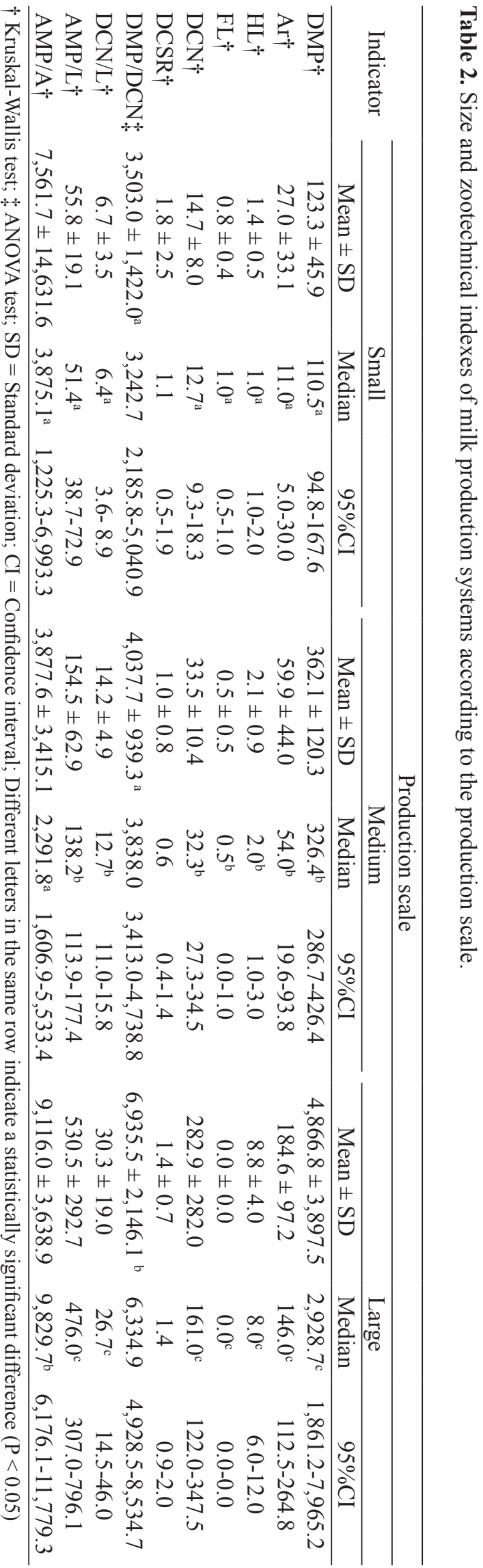


In this study, the index profitability 1 was $-2.6,3.2$, and $5.4 \%$, whereas the index return 1 was $-0.6,1.1$, and $1.5 \%$ for small-, medium-, and large-scale productions, respectively. No significant difference $(\mathrm{P}>0.05)$ was observed among the groups for both indexes (Table 3 ). To estimate the indexes profitability 1 and return 1, the net profit is taken into consideration, which include the return on capital and land. Herein, to further clarify the analysis of the results, the indexes profitability 2 and return 2, which include the net margin instead of net profit, were also calculated (LOPES et al., 2011). Such values may be compared to a savings account, which allows for improved comparisons. Profitability 2 was $19.6,32.1$, and $15.7 \%$ for the small-, medium-, and large-scale productions and significantly different $(\mathrm{P}<0.05)$ between medium and large producers. The values of return 2 were $5.6,13.3$, and $6.4 \%$ for the small-, medium-, and large-scale groups, respectively, and significantly different $(\mathrm{P}<0.05)$ to the medium production scale. Although greater investments of capital are expected to generate better economic results, in our sample of herds, medium producers showed "healthier" and more attractive indexes. Thus, the relatively high levels of technical and allocative production factors' efficiency among the medium scale farmers defy the notion that milk can only be profitable when produced by the large-scale farmers. The efficiency level of the dairy farmers is the main determinant of the economic results.

A significant difference $(\mathrm{P}<0.05)$ was observed in relation to the item food, which accounted for $60.1,58.4$, and $56.3 \%$ of the EOC and 32.1, 38.0, and $50.0 \%$ of the total costs of small-, medium-, and large-scale productions, respectively (Figure 1). These high percentages corroborate with other studies (SANTOS et al., 2005; LOPES et al., 2004), and indicate that dairy farmers should pay special attention to food costs as small savings that do not sacrifice food quality and a balanced diet results in a considerable reduction of the EOC, which affects the profitability and return of the activity. It is also important to consider that the low food cost associated with high production efficiency may result in better indexes in economic terms. However, the reduced representativeness of food does not necessarily indicate greater efficiency within the production unit or higher earnings as these values are expressed as a percent of the EOC and TC, and increase proportionally the remaining items.

The percentages related to labor were 12.8, 16.6, and $16.0 \%$ of the EOC for small-, medium-, and large-scale productions, respectively, and no significant difference $(\mathrm{P}>0.05)$ was observed among the groups (Figure 1). The low percentage of EOC for the small-scale productions resulted from the greater use of FL, which caused a decrease in hired staff and labor expenses. Conversely, the percentages were $6.6,10.9$, and $14.0 \%$ when considering the TC of small-, medium-, and largescale productions, respectively, with significant differences $(\mathrm{P}<0.05)$ among the groups (Figure 1). The smaller percentage of the small-scale group partly results from the greater use of FL and greater fixed costs, which contributed to reducing the percentages of the other items, including labor.

Expenses for herd health, breeding, and milking were significantly greater $(\mathrm{P}<0.05)$ for the largescale production group (Figure 1), possibly owing to the greater herd health control, and use of reproductive biotechnologies and mechanical milking. Nevertheless, these expenses had low representativeness in the EOC, which highlights that it is pointless to specifically focus on managerial and technological solutions to reduce these expenses or discontinue the use of certain inputs that are considered important, including those intended for animal health, which have significant effects on productivity but are insignificant to the production costs. 
Figure 1. Effects of production scale on the representativeness $(\%) \pm \mathrm{SD}$ of components of effective operational cost (A) and total cost (B) of 61 typical Brazilian dairy farms.
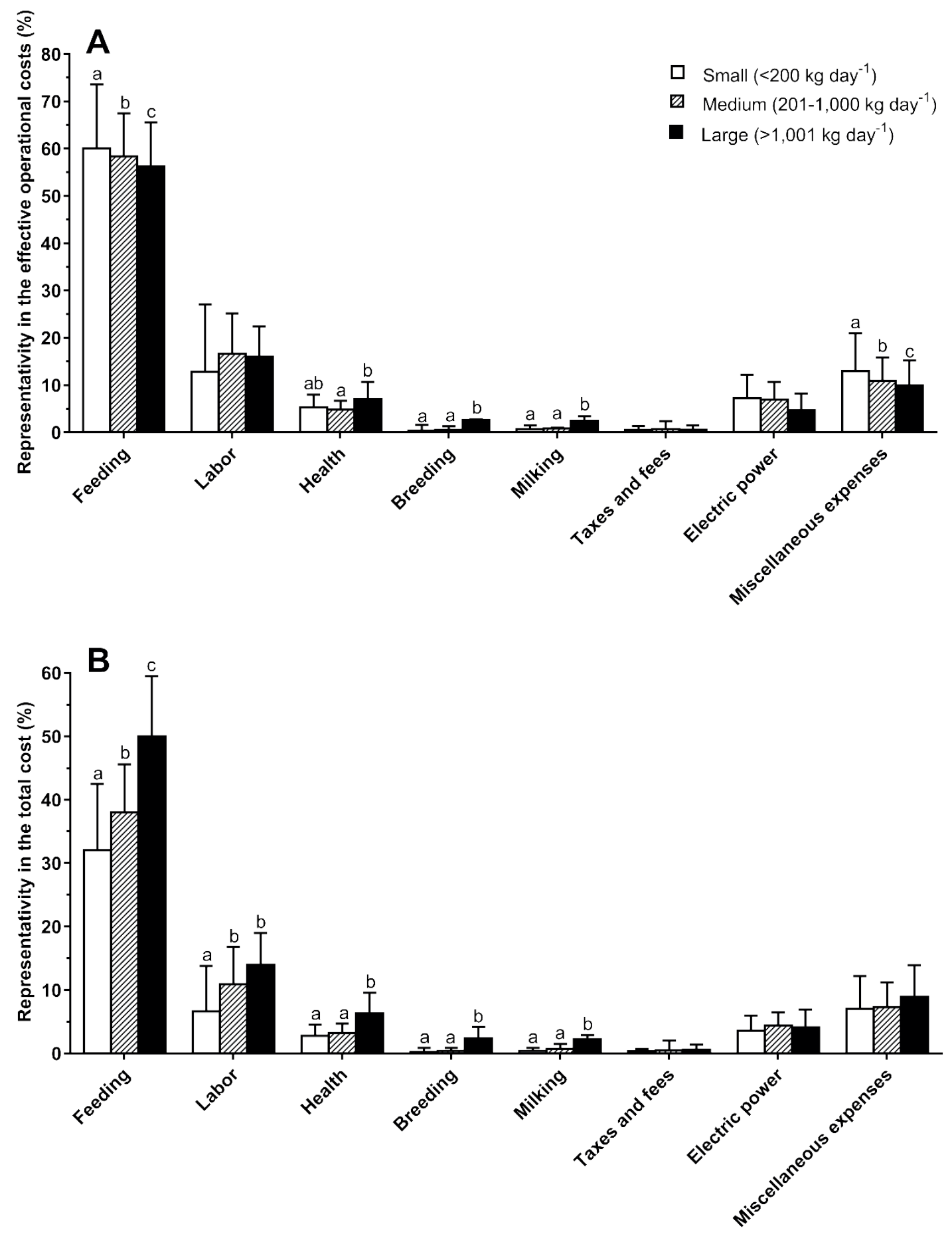
Based on the above statements, we conclude that the factor production scale resulted in a considerable amount of significant differences among the groups studied. Therefore, it is an adequate criterion in analyses among different groups of producers, and it is more easily obtained and probably provides more accurate results. The milk production systems studied showed better zootechnical indexes than those found in average Brazilian farms. However, the indexes were lower than international indexes or those of technologically advanced farms from other Brazilian regions, which indicates the need for regionalized studies and potential opportunities to improve both zootechnical and economic efficiencies. Greater production scale is a desired condition, although it failed to ensure the economic efficiency of the herds studied. The items that were most representative of the total and effective operating costs were, in descending order, food and labor.

\section{Acknowledgments}

The authors acknowledge the contributing producers for providing data used in this research. This work was funded by Minas Gerais Research Foundation (FAPEMIG) (Grant number SHA APQ 01974/11) and National Council for Scientific and Technological Development (CNPq).

\section{References}

ARÊDES, A.; SILVEIRA, S. F. R.; LIMA, A. A. T. F. C.; ARÊDES, A. F.; PIRES, S. V. Análise de custos na pecuária leiteira: um estudo de caso das propriedades assistidas pelo programa de desenvolvimento da pecuária leiteira da Região de Viçosa. Custos e @gronegócios on line, Recife, v. 2, n. 1, p. 45-68, 2006.

DEMEU, F. A.; LOPES, M. A.; COSTA, G. M.; ROCHA, C. M. B. M.; SANTOS, G.; DETO, A. F. Influência do descarte involuntário de matrizes no impacto econômico da mastite em rebanhos leiteiros. Ciência e Agrotecnologia, Lavras, v. 35, n. 1, p. 195-202, 2011.

DUQUIA, R. P.; BASTOS, J. L. D. Medidas de tendência central: onde a maior parte dos indivíduos se encontra?
Scientia Medica, Porto Alegre, v. 16, n. 4, p. 190-194, 2006.

FASSIO, L. H.; REIS, R. P.; GERALDO, L. G. Desempenho técnico e econômico da atividade leiteira em Minas Gerais. Ciência e Agrotecnologia, Lavras, v. 30, n. 6, p. 1154-1161, 2006.

FEDERAÇÃO DE AGRICULTURA DO ESTADO DE GOIÁS - FAEG. Diagnóstico da cadeia produtiva do leite de Goiás. Goiânia: Talento, 2009. 64 p.

FEDERAÇÃO DE AGRICULTURA DO ESTADO DE MINAS GERAIS - FAEMG. Diagnóstico da pecuária leiteira do estado de Minas Gerais em 2005: relatório de pesquisa. Belo Horizonte: Rona, 2006. 156 p.

FERRAZZA, R. A.; LOPES, M. A.; BRUHN, F. R. P.; MORAES, F.; CARVALHO, F. M. Effect of husbandry system on the technical and economic performance of dairy cattle. Semina: Ciências Agrárias, Londrina, v. 38, n. 3, p. 1561-1574, 2017.

GOMES, S. T. Transformações na produção do leite. Indústria de Laticínios, São Paulo, v. 5, n. 26, p. 14-16, 2000.

GONÇALVES, R. M. L.; VIEIRA, W. C.; LIMA, J. E.; GOMES, S. T. Analysis of technical efficiency of milkproducing farms in Minas Gerais. Economia Aplicada, Ribeirão Preto, v. 12, n. 2, p. 321-335, 2008.

HEMME, T.; UDDIN, M. M.; NDAMBI, O. A. Benchmarking cost of milk production in 46 countries. Journal of Reviews on Global Economics, Ontario, v. 3, n. 1, p. 254-270, 2014.

HOFFMANN, R. Administração da empresa agrícola. São Paulo: Pioneira, 1987. 325 p.

KRUG, E. E. B. Estudo para identificação de benchmarking em sistemas de produção de leite no Rio Grande do Sul. 2001. Dissertação (Mestrado em Administração) - Universidade Federal do Rio Grande do Sul, Porto Alegre.

LOPES, M. A.; RESENDE, M. C.; CARVALHO, F. M.; CARDOSO, M. G. Estudo da rentabilidade de sistemas de produção de leite na região de Nazareno (MG)6cON. Ciência Animal Brasileira, Goiânia, v. 12, n. 1, p. 58-69, 2011.

LOPES, M. A.; CARDOSO, M. G.; CARVALHO, F. M.; LIMA, A. L. R.; CARDOSO, M. G.; CARMO, E. A. Efeito da escala de produção nos resultados econômicos de sistema de produção de leite na região de Lavras (MG) em 2004 e 2005. Archivos Latinoamericanos de Producción Animal, Maracaibo, v. 16, n. 3, p. 121-129, 2008. 
LOPES, M. A.; CARDOSO, M. G.; CARVALHO, F. M.; LIMA, A. L. R.; DIAS, A. S. Efeito do tipo de sistema de criação nos resultados econômicos de sistema de produção de leite na região de Lavras (MG) em 2004 e 2005. Ciência Animal Brasileira, Goiânia, v. 8, n. 3, p. 359-371, 2007.

LOPES, M. A.; LIMA, A. L. R.; CARVALHO, F. M.; REIS, R. P.; SANTOS, I. C.; SARAIVA, F. H. Controle gerencial e estudo da rentabilidade de sistemas de produção de leite na região de Lavras (MG). Ciência e Agrotecnologia, Lavras, v. 28, n. 4, p. 883-892, 2004.

LOPES, M. A.; CARDOSO, M. G.; DEMEU, F. A. Influência de diferentes índices zootécnicos na composição e evolução de rebanhos bovinos leiteiros. Ciência Animal Brasileira, Goiânia, v. 10, n. 2, p. 446453, 2009.

MARQUES, V. M.; REIS, R. P.; SÁFADI, T.; REIS, A. J. Custos e escala na pecuária leiteira: estudo de casos em Minas Gerais. Ciência e Agrotecnologia, Lavras, v. 26 n. 5, p. 1027-1034, 2002.

MATSUNAGA, M.; BEMELMANS, P. F.; TOLEDO, P. E. N. Metodologia de custo de produção utilizado pelo IEA. Agricultura em São Paulo, São Paulo, v. 23, n. 1, p. 123-139, 1976.

MORAES, A. C. A.; COELHO, S. G.; RUAS, J. R. M.; RIBEIRO, J. C. V. C.; VIEIRA, F. A. P.; MENEZES, A. C. Estudo técnico e econômico de um sistema de produção de leite com gado mestiço F1 Holandês-Zebu. Arquivo Brasileiro de Medicina Veterinária e Zootecnia, Belo Horizonte, v. 56, n. 1-4, p. 745-749, 2004.
NASCIF, C. Indicadores técnicos e econômicos em sistemas de produção de produção de leite de quatro mesorregiões do estado de Minas Gerais. 2008. Dissertação (Mestrado em Economia Rural) Universidade Federal de Viçosa, Viçosa, MG.

OLIVEIRA, T. B. A.; FIGUEREDO, R. S.; OLIVEIRA, M. W.; NASCIF, C. Índices técnicos e rentabilidade na pecuária leiteira. Scientia Agricola, v. 58, n. 4, p. 687692, 2001.

SANTOS, J. A.; VIEIRA, W. C.; BAPTISTA, A. J. M. Eficiência técnica em propriedades leiteiras da microrregião de Viçosa-MG: uma análise nãoparamétrica. Organizações Rurais e Agroindustriais, Lavras, v. 7, n. 2, p. 162-172, 2005.

SCHIFFLER, H. A.; MÂNCIO, A. B.; GOMES, S. T.; QUEIROZ, A. C. Efeito da escala de produção nos resultados econômicos da produção de leite B no Estado de São Paulo. Revista Brasileira de Zootecnia, Viçosa, MG, v. 28, n. 2, p. 425-431, 1999.

SILVA, H. A. Resultados econômicos de sistemas de produção de leite com diferentes níveis tecnológicos na Cooperativa Agropecuária Castrolanda, Castro, PR. In: CONGRESSO PAN-AMERICANO DO LEITE, 9., 2006, Porto Alegre. Anais... Porto Alegre: EMBRAPA, 2006. CD-ROM.

STEPHENSON, M. W. U. S. Top dairies: benchmarks for success. In: AGRICULTURAL OUTLOOK FORUM 2000, 2000, Arlington. Proceeding... Arlington: U. S. Department of Agriculture, 2000. p. 1-13. Available at: <http://ageconsearch.umn.edu/record/33453/files/ fo00st01.pdf $>$. Accessed at: 14 oct. 2015 . 
